\title{
Food availability effects on reproductive strategy: the case of Acartia tonsa (Copepoda: Calanoida)
}

\author{
E. Acheampong ${ }^{1, *}$, R. W. Campbell ${ }^{2}$, A. B. S. Diekmann ${ }^{1}$, M. A. St. John ${ }^{1}$ \\ ${ }^{1}$ Institut für Hydrobiologie und Fischereiwissenschaft, Grosse Elbstrasse 133, 22767 Hamburg, Germany \\ ${ }^{2}$ Prince William Sound Science Center, Cordova, Alaska 99574, USA
}

\begin{abstract}
Food availability has been linked to changes in the biochemical composition of zooplankton eggs. However, a number of species are capable of resource storage and are thereby able to use accumulated reserves for reproduction during periods of poor food conditions. Conversely, in species such as Acartia tonsa with limited storage capacities, there can be a strong dependence of egg composition on ambient food conditions. The aim of this study was to determine the effect of food availability on the carbohydrate, protein and fatty acid composition of $A$. tonsa females and their eggs after being fed with different concentrations of the cryptophyte Rhodomonas baltica. During the experiments, no significant differences in the biochemical composition of females were observed, although egg protein composition was higher in food-limited females. We propose that the production of protein-rich eggs by food-limited copepods is a reproductive strategy for ensuring the survival of offspring during poor feeding conditions. In terms of their relative biochemical makeup, there were no significant differences between both adults and eggs of $A$. tonsa and their prey $R$. baltica. However, these biochemical similarities did not influence egg production. Rather, higher biochemical similarities were observed between $R$. baltica and eggs when females were food limited. These findings suggest that food-limited females may moderate the cost of reproduction by producing eggs without much modification to the substrates they ingest.
\end{abstract}

KEY WORDS: Acartia tonsa $\cdot$ Food concentration $\cdot$ Biochemical content $\cdot$ Resting eggs

\section{INTRODUCTION}

Copepods occupy a key trophic position in marine food webs and are responsible for the transfer of a large proportion of the energy between primary producers and higher trophic levels (Cushing 1990). Vital for the persistence of copepod populations is the production of viable eggs that ensure the supply of naupliar recruits and hence the survival of individual populations. Among other factors, normal development and subsequent hatching of eggs depends on their chemical constituents. For example, carbohydrates are mainly used as an energy source during hatching (Guisande \& Harris 1995), proteins modulate cellular events such as gene expression and growth, and fatty acids (FAs, specifically polyunsaturated FAs) are involved in the metabolism of chemicals responsible for regulating cell differentiation and hatching (Sessler \& Ntambi 1998). Often these roles are specific to individual biochemical constituents, and they are typically not interchangeable. Several studies have demonstrated the effect of prey biochemical contents on egg viability (e.g. Jónasdóttir \& Kiørboe 1996, Guisande et al. 2000). However, it is not clear whether egg viability is also affected by food availability (e.g. Tang et al. 1998).

Food availability influences egg size, which influences the amount of chemical substances required for embryogenesis and subsequent hatching (Guisande \& Harris 1995, Auel 2004). Furthermore, the extent to which ambient food levels influence egg biochemical characteristics may depend on the reproductive strategy of animals. For example, during poor food conditions, species capable of storing lipids rely mostly on 
accumulated reserves for reproduction (Lee et al. 2006). This adaptive strategy, where trophic history plays a key role, removes the lipid requirement for egg production from the immediate nutritional needs of females, thus buffering the dependence of egg lipid composition on the prevailing ambient food conditions (e.g. Paraeuchaeta antartica; Alonzo et al. 2000). Conversely, in species with a reduced capacity for the storage of lipids, the dependence of egg lipid composition on ambient food conditions can be marked (see Ederington et al. 1995). Furthermore, the effect of ambient food variability on compounds such as proteins and carbohydrates that are not stored in large amounts by copepods has the potential to be significant and possibly independent of species' reproductive strategies. However, this issue has been investigated only in eggs produced by species capable of accumulating resources (e.g. Alonzo et al. 2000).

Acartia tonsa is a common euryhaline copepod in estuarine and coastal waters, and does not store appreciable amounts of reserve biomass (Lee et al. 2006). Several studies have demonstrated the effect of food availability on biochemical composition of the species (Mayzaud 1976, Roman 1991, Ederington et al. 1995). Most investigations have considered the extremes of the food availability spectrum, with copepods either starved or fed at saturating levels (e.g. Mayzaud 1976, Ederington et al. 1995), and rarely has the effect of food availability on egg biochemical composition been considered (Ederington et al. 1995). As a result, the biochemical composition of the eggs $A$. tonsa produces when fed below saturation food levels are not known. As has been done for other copepod species (e.g. Guisande \& Harris 1995), the effect of low food conditions on the biochemical composition of A. tonsa eggs also needs to be investigated because low food conditions are a feature of the natural environments of the species (Bellantoni \& Peterson 1987, Durbin et al. 1992).

The aim of the present study was to determine whether the biochemical content (i.e. protein, carbohydrate and FA) of Acartia tonsa varies in relation to the quantity of food available, and whether such variation could affect the chemical composition of its eggs. Huntley \& Boyd (1984) suggested that zooplankton have a minimum maintenance food concentration, which is required to balance respiratory losses. Furthermore, the potential for a chemical substance to limit the growth of zooplankton varies as the demand for biochemical substances varies with food quantity (Sterner 1997). Hence, we hypothesize that sub-optimal amounts of food (i.e. food quantity limitation) cause females to produce eggs with a chemical composition dissimilar to those produced by individuals provided with an adequate amount of food, due to the energy demand for maintenance.

\section{MATERIALS AND METHODS}

Algal culture. The cryptophyte Rhodomonas baltica (clone RCC 350) was used as a food source. The algae were maintained in a continuous culture in $33 \mathrm{psu}$ seawater at $20 \pm 1.5^{\circ} \mathrm{C}$ under an $11: 13 \mathrm{~h}$ light:dark cycle with a photo-saturating light intensity $(\sim 100 \mu \mathrm{E}$ $\mathrm{m}^{-2} \mathrm{~s}^{-1}$ ). Light intensity was monitored daily using a TriOS ACC VIS spectral irradiance meter. The algae were maintained in Walne's medium (McVej 1993) and kept in an exponential growth phase by replacing approximately half of the culture with fresh medium daily. The cultures were continually aerated (to prevent self-shading and ensure mixing). Prior to being fed to the copepods, daily triplicate samples of the algae were filtered onto a pre-combusted Whatman $\mathrm{GF} / \mathrm{F}$ filter and immediately stored at $-80^{\circ} \mathrm{C}$ for later determination of biochemical constituents. Each filter contained at least $3 \times 10^{6}$ cells, an amount determined to be sufficient from preliminary experiments.

Copepod cultures. Batches of Acartia tonsa eggs were placed in filtered seawater and incubated in a 501 polyethylene tank. After hatching, the cultures were fed a daily ration of the experimental diet at con-

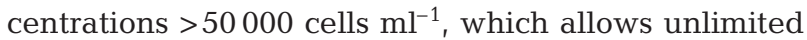
growth (Kiørboe et al. 1985). Algal cell counts were made daily with a Beckman Multisizer 3. Cultures were maintained at the same light, salinity and temperature as the algae and received gentle aeration for mixing. Only young adults (ca. 3 wk after hatching) from the same batch of eggs were used for the experiments. Copepods were conditioned to the experimental prey concentration for $24 \mathrm{~h}$.

After the conditioning period, groups of 50 individuals (40 females and 10 males) were placed in meshbottom sieves (130 $\mu \mathrm{m}$ mesh size) and suspended in $1 \mathrm{l}$ beakers at 3 different food concentrations (110, 550 and $1100 \mu \mathrm{g} \mathrm{C} \mathrm{l}^{-1}$ ). A carbon content of $36.7 \mathrm{pg} \mathrm{cell}^{-1}$ (Kiørboe et al. 1985) was assumed in estimating the number of Rhodomonas baltica cells needed to meet the carbon requirement at each food concentration. Nine setups were established for each food concentration, with 3 replicates for each biochemical considered.

Every $24 \mathrm{~h}$, the adult copepods were placed into new beakers with fresh food (at the same experimental level) by carefully transferring the sieves. The contents of the old beakers were sieved through a $35 \mu \mathrm{m}$ sieve, followed by several washings with double-filtered seawater, and rinsed into a Bogorov counting tray. The number of eggs was counted under a binocular microscope at $16 \times$ magnification. Using forceps and pins, individual eggs were freed of faecal pellets and detritus before transferring them into a new beaker using a small pipette. Seven to 10 eggs were then sub-sampled from each beaker for egg size measurement. 
Egg size measurements were made by photographing eggs with a digital camera (Leica DC300) connected to an image analysis system (IMAGEPRO plus 4.5.1) mounted on an inverted microscope at 400x magnification. The diameter of circles drawn to cover the outline of the images on the screen was used to estimate egg diameter. Three circles were drawn for each egg, and the mean of the 3 measurements was used to represent egg diameter.

The remaining eggs (between 120 and 250) were filtered onto a pre-combusted Whatman GF/F filter, and immediately stored at $-80^{\circ} \mathrm{C}$ for later analysis of biochemical composition. Using these methods, samples were collected from each replicate beaker every day for $3 \mathrm{~d}$ (Day 1, 2, and 3). At the end of the trials, copepods were checked for mortality, and all remaining females (between 20 and 32) were filtered onto a pre-combusted Whatman GF/C filter, washed with isosmotic ammonium formate to remove excess salts, and immediately stored at $-80^{\circ} \mathrm{C}$. The number of copepods and eggs filtered for biochemical analysis are comparable with those used in similar studies (Ederington et al. 1995).

Biochemical analysis. Protein content was measured with the Bicinchoninic acid assay of Smith et al. (1985). Absorbance was measured at $562 \mathrm{~nm}$ and calibrated with a bovine serum albumin (BSA) standard.

Total carbohydrate was measured following the sulphuric acid-phenol method of Herbert et al. (1971) and Dubois et al. (1956), and expressed as glucose equivalents. Absorbance was read at $490 \mathrm{~nm}$.

Lipids were extracted following the method of Folch et al. (1957) in 8:4:3 dichloromethane: methanol:water; a known concentration of nonadecanol was added as an internal standard. Samples were vortexed, placed on ice in a sonication bath for $30 \mathrm{~min}$, and stored at $-20^{\circ} \mathrm{C}$ overnight. Transesterification of FAs was performed following the method of Kattner \& Fricke (1986) and analysed by capillary gas chromatography using an Agilent Technologies 6890N Network GC System with flame ionisation detection. Separations were performed with a DB-WAX capillary column (30 $\mathrm{m}$ long and $0.32 \mathrm{~mm}$ inner diameter) with helium as the carrier gas at $68.9 \mathrm{kPa}$. The temperature program was $40^{\circ} \mathrm{C}$ to $150^{\circ} \mathrm{C}$ at a rate of $10^{\circ} \mathrm{C} \mathrm{min}{ }^{-1}$ followed by $20^{\circ} \mathrm{C} \mathrm{min}^{-1}$ to $220^{\circ} \mathrm{C}$. FA methyl esters were detected at $250^{\circ} \mathrm{C}$. Chromatographic data were collected with a data system (Chemstation, Hewlett-Packard) and quantified by comparison of peak areas with the internal standard. The FA content of an organism was calculated as the sum of all the individual FAs detected.

Data analysis. Only samples collected on the last day of the experiment were analysed by performing an ANOVA. Tests were done using the ANOVAN function of MATLAB for Windows (v. 7.0.4). ANOVAN allows for the multi-way ANOVA for variable observa- tions with respect to any number of different factors. Unless stated, the critical p-value was taken to be 0.05 . Whenever differences were found between any set of data, the Tukey's HSD ( $\alpha=0.05)$ procedure was used as a post hoc test to determine which pairs of means were significantly different.

Within-group tests (e.g. biochemical composition of female Acartia tonsa or eggs in the different treatments) were done on measured compositions for each component (i.e. mass ind. ${ }^{-1}$ ). One-way ANOVA was used to compare the composition of individual biochemicals between food treatments. Whenever 2 dissimilar groups were compared (females vs. eggs vs. food), all biochemical constituents were converted into proportions and arcsine transformed prior to analysis. When multiple 1-way ANOVAs were done, the critical p-value was Bonferroni corrected by dividing 0.05 by the number of tests. Where no significant differences in relative chemical compositions were found between experimental organisms, a dissimilarity index was used to determine how the biochemical similarities between eggs, food and copepods relate to egg production rate. A pairwise Euclidean distance $\left(D_{\mathrm{JK}}\right)$ was used to estimate dissimilarity between the constituents of females, their eggs and the food:

$$
D_{\mathrm{JK}}=\frac{\sqrt{\sum_{i=1}^{n}\left(X_{i \mathrm{~J}}-X_{i \mathrm{~K}}\right)^{2}}}{\mathrm{n}}
$$

where $X_{i J}$ and $X_{i \mathrm{~K}}$ are the proportions of the biochemi$\mathrm{cal} i$ of the females or eggs $(\mathrm{J})$ and the food $(\mathrm{K})$, and $\mathrm{n}$ is the number of biochemical constituents. In the present study, $D_{\mathrm{JK}}$ indicates the distance between organisms in an FA-protein-carbohydrate space, so the value of $D_{\text {JK }}$ would be larger if organisms being compared were less similar and vice versa. Prior to calculating $D_{\text {JK }}$, the data were standardized to have 0 mean and unit standard deviation to remove the effect of differences in magnitude of the different constituents.

\section{RESULTS}

\section{Biochemical contents of the algae, copepods and eggs}

The different biochemicals had differing contributions to total measured organic content in the experimental Rhodomonas baltica diet (Fig. 1). Carbohydrates were the major biochemical constituent (about 69 to $82 \%$ on average), followed by proteins (14 to $30 \%$ ) and FAs (1 to $4 \%$ ). Testing for differences in the food between days is difficult, because the amounts can be expected to be autocorrelated, and the shortterm nature of the experiments (samples from only $3 \mathrm{~d}$ ) makes detection of a trend unlikely. Given that the cul- 


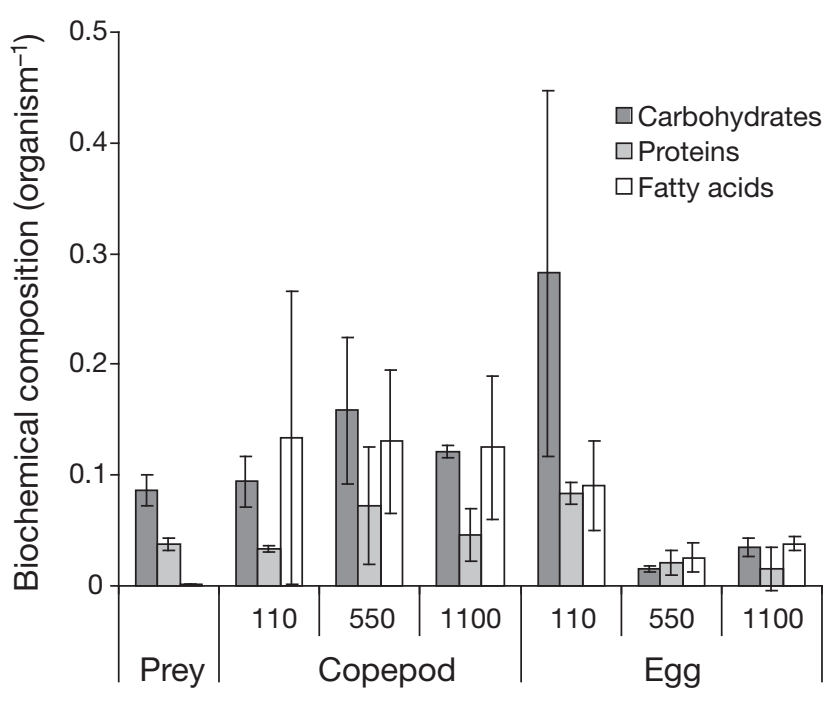

Fig. 1. Biochemical constituents (mean $\pm \mathrm{SD}, \mathrm{n}=3$ ) of experimental food (prey, ng), and Acartia tonsa females $(\mu \mathrm{g} \times 10)$ and their eggs $(\mu \mathrm{g})$ after the copepods were fed at 110, 550 and $1100 \mu \mathrm{g} \mathrm{C}^{-1}$ food concentrations

tures were grown semi-continuously (i.e. nutrients added daily), we assumed that the composition of the food did not change over time.

Differences between individual biochemical constituents of females held at different food concentrations were tested via 1-way ANOVA. There were no significant differences in the biochemical composition of the females among the 3 food treatments (Fig. 1, carbohydrate: $F_{2}=1.07, \mathrm{p}=0.4105$; proteins: $F_{2}=0.64, \mathrm{p}=$ 0.5648 and FA: $F_{2}=0.47, \mathrm{p}=0.6577$ ).

FA, protein and carbohydrate contents (mean $\pm \mathrm{SD}$ ) of females were respectively $1.31 \pm 1.33,0.51 \pm 0.70$ and 1.25 $\pm 1.58 \mu \mathrm{g}$ ind. $^{-1}$.

Differences between individual biochemical constituents of eggs produced at different food concentrations were tested via 1-way ANOVA. Egg carbohydrate $\left(F_{2}=6.86, \mathrm{p}=0.0509\right)$ and FA $\left(F_{2}=5.22, p=0.0767\right)$ contents did not change significantly with food concentration, being respectively $0.11 \pm 0.28$ and $0.05 \pm 0.09 \mu \mathrm{egg}^{-1}$. Only the protein content of eggs differed significantly between treatments $\left(F_{2}=12.54, \mathrm{p}=0.0189\right)$ and was significantly higher in eggs produced by food-limited $\left(110 \mu \mathrm{g} \mathrm{C} \mathrm{l}^{-1}\right)$ in comparison to food-saturated (550 and $1100 \mu \mathrm{g}$ $\mathrm{C}^{-1}$ ) females (Tukey's HSD post hoc test, $\mathrm{p}<0.05$ ). On average, protein composition decreased from 0.08 to $0.02 \mu \mathrm{g} \mathrm{egg}^{-1}$ with increasing food availability.

To determine whether the individual biochemical constituents of Acartia tonsa and their eggs reflect that of their prey, the relative biochemical composition of all treatment groups (Rhodomonas baltica, A. tonsa females and eggs at the 3 feeding levels; see Fig. 1) were compared using a 1-way ANOVA. There were no significant differences between Acartia females and their food, or between Acartia eggs and the experimental diet for any of the biochemical substances (carbohydrate: $F_{6}=3.02, \mathrm{p}=0.059$; protein: $F_{6}=1.39, \mathrm{p}=0.34 ;$ FAs: $\left.F_{6}=2.99, \mathrm{p}=0.061\right)$. Furthermore, there were no significant differences between females and eggs at any of the feeding levels, for any of the biochemicals (Table 1). A dissimilarity index $\left(D_{\mathrm{JK}}\right)$ was therefore used to determine how these relative biochemical similarities between experimental organisms relate to the rate of egg production by the copepod.

\section{Egg size, production rate and biochemical dissimilarities between experimental organisms}

Fig. 2 shows the effect of food concentration on egg size and production rate. There were no significant differences in egg size at the 3 food concentrations on Day 2 (1-way ANOVA, $F_{2}=0.76, \mathrm{p}=0.49$ ) or Day 3 (1-way ANOVA, $\left.F_{2}=0.45, \mathrm{p}=0.64\right)$. Egg production rate was different between both days and the feeding treatments (Table 2). Again, the inclusion of a 'day' term leaves open the possibility of temporal autocorre-

Table 1. Acartia tonsa. Two-way ANOVA testing for difference between stage (adult female or egg) and feeding level $\left(110,550\right.$ and $1100 \mu \mathrm{g} \mathrm{C} \mathrm{l}^{-1}$ ) in the feeding experiments, by biochemical

\begin{tabular}{|llcrccc|}
\hline Biochemical & Source & SS & df & MS & $F$ & $\mathrm{p}$ \\
\hline Carbohydrate & Stage & 0.01116 & 1 & 0.01116 & 0.49 & 0.5014 \\
& Level & 0.01058 & 1 & 0.01058 & 0.46 & 0.5124 \\
& Stage $\times$ Level & 0.08213 & 1 & 0.08213 & 3.58 & 0.0877 \\
& Error & 0.22934 & 10 & 0.02293 & & \\
& Total & 0.32241 & 13 & & & \\
Protein & Stage & 0.0305 & 1 & 0.0305 & 2.46 & 0.148 \\
& Level & 0.02218 & 1 & 0.02218 & 1.79 & 0.2109 \\
& Stage $\times$ Level & 0.01957 & 1 & 0.01957 & 1.58 & 0.2377 \\
& Error & 0.1241 & 10 & 0.01241 & & \\
& Total & 0.18197 & 13 & & & \\
& Stage & 0.00476 & 1 & 0.00476 & 0.13 & 0.7225 \\
& Level & 0.00212 & 1 & 0.00212 & 0.06 & 0.8123 \\
& Stage $\times$ Level & 0.02152 & 1 & 0.02152 & 0.6 & 0.4555 \\
& Error & 0.35694 & 10 & 0.03569 & & \\
& Total & 0.40188 & 13 & & & \\
\hline
\end{tabular}




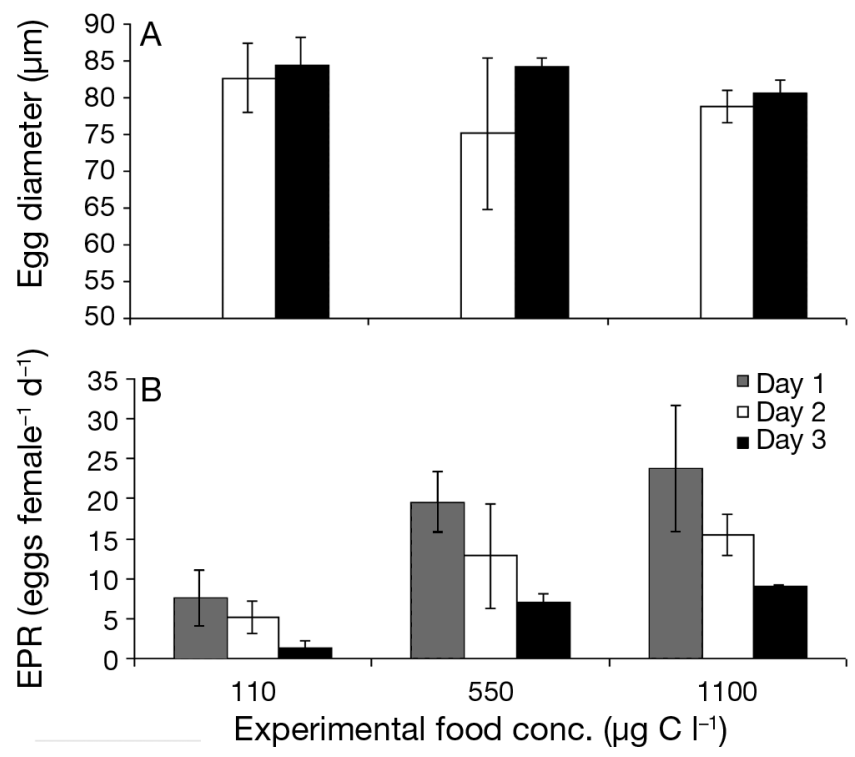

Fig. 2. Acartia tonsa. Mean $\pm \mathrm{SD}$ of (A) egg diameter and (B) egg production rate (EPR) of copepods kept at different food concentrations over a period of $3 \mathrm{~d} . \mathrm{N}=9$ for each day and food concentration

Table 2. Acartia tonsa. Two-way ANOVA testing for the effect of treatment day and food concentration (3 treatments: 110, 550 and $1100 \mu \mathrm{g} \mathrm{C} \mathrm{l}^{-1}$ ) on egg production rate

\begin{tabular}{|lrrcrl|}
\hline Source & SS & df & MS & $F$ & $p$ \\
\hline Day & 1312.8 & 2 & 656.4 & 5.36 & 0.0068 \\
Food conc. & 1857.9 & 2 & 928.9 & 7.59 & 0.001 \\
Day $\times$ Food conc. & 322.9 & 4 & 80.724 & 0.66 & 0.62 \\
Error & 8691.2 & 71 & 122.4 & & \\
Total & 12239.3 & 79 & & & \\
\hline
\end{tabular}

lation, although the danger with an autocorrelation would be a Type II error (finding no difference when one did exist), so the significant result can be considered conservative. A post hoc Tukey test found that egg production on Day 1 was significantly higher than on Day 3, but that Day 2 was not significantly different from either day. A post hoc Tukey test found that egg production rate in the lowest feeding treatment $\left(110 \mu \mathrm{g} \mathrm{C} \mathrm{l}^{-1}\right)$ was significantly lower than in the 2 highest treatments (550 and $1100 \mu \mathrm{g} \mathrm{C} \mathrm{l}^{-1}$ ), but that there were no significant differences between the 2 highest treatments. These results indicate that egg production by females held at the lowest food level was limited by food availability.

Furthermore, egg production rate was correlated with the dissimilarity between the biochemical composition of the prey and both Acartia tonsa (Fig. $3 \mathrm{~A}_{i} \mathrm{r}^{2}=$ 0.59, $\mathrm{p}=0.0447$ ) and eggs (Fig. $3 \mathrm{~B}_{;} \mathrm{r}^{2}=0.68, \mathrm{p}=$
0.0117). Shortest dissimilarity distances (with 1 outlier) were observed in the low food treatments where egg production rates were low. Egg production rate was independent of the biochemical similarities between eggs and females (Fig. $3 C_{i} r^{2}=0.01, p=0.1857$ ).
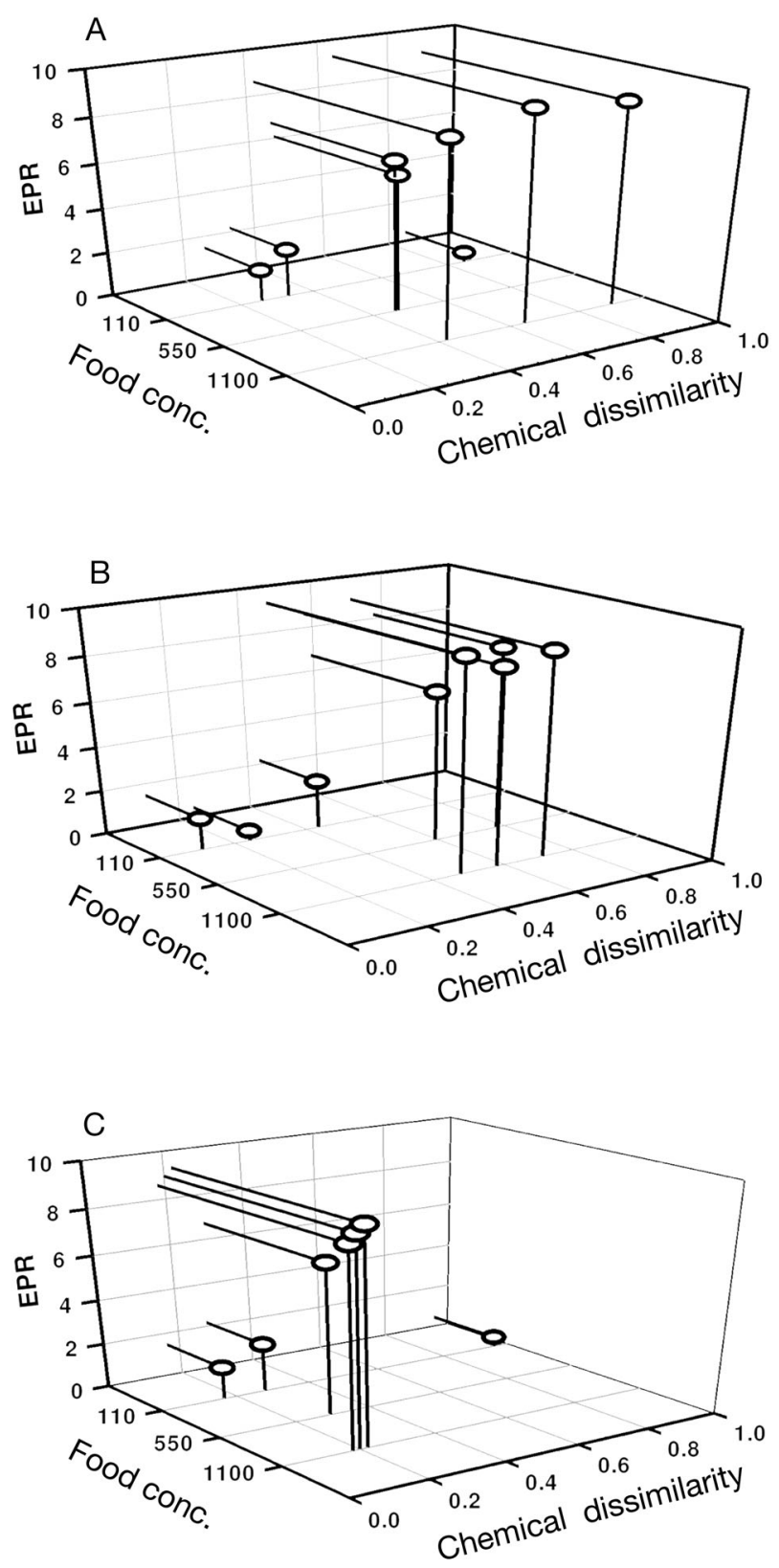

Fig. 3. Acartia tonsa. Effect of food availability on the relationship between egg production rate (EPR, mean of 3 samples) and the biochemical similarity between (A) females and their food $\left(y=11.47 x+0.49 ; r^{2}=0.59, p=0.0447\right)$, (B) females' food and eggs $\left(y=13.60 x-0.94 ; r^{2}=0.68, p=0.0117\right)$ and $(C)$ eggs and females $\left(y=-6.71 x+7.70 ; r^{2}=0.01, p=0.1857\right)$. A smaller dissimilarity indicates organisms being compared are more similar and vice versa 


\section{DISCUSSION}

\section{Egg production and biochemical similarities between predator and prey}

The goal of the present study was to investigate the effect of food quantity on the biochemical composition of female copepods and their eggs. Acartia tonsa was chosen for the study because it has been demonstrated that carbon ingested by adult females of the species appears rapidly in their eggs $(<10 \mathrm{~h}$ : Tester \& Turner 1990), therefore making it a good candidate for shortterm laboratory experiments regarding the possible changes in the biochemical composition of eggs as well as adults. Furthermore, $A$. tonsa is omnivorous and capable of food selection (Cowles et al. 1988). It can therefore feed to satisfy its optimum requirement for specific substances, given the broad mixture of in situ prey species, trophic types and biochemical composition. This has been observed in field studies involving other copepod species (Pond et al. 1996, Peters et al. 2007). In the present study, we raised Acartia on a single prey with the same biochemical composition; this may force feeding to be non-selective, and as a consequence limit the diversity of biochemical resources the copepod might otherwise acquire for biosynthesis. Moreover, $A$. tonsa does not store appreciable amounts of reserve biomass (Lee et al. 2006) that could serve as a buffer against biochemical limitations of a uni-algal diet.

Egg production of Acartia spp. has been the subject of much research (e.g. Kiørboe et al. 1985, Jónasdóttir \& Kiørboe 1996), and egg production rate has been reported to be 10 to 50 eggs female ${ }^{-1} \mathrm{~d}^{-1}$, which compares with the rates observed in the present study ( 2 to 33 eggs female ${ }^{-1} \mathrm{~d}^{-1}$ ). At $110 \mu \mathrm{g} \mathrm{C} \mathrm{l}^{-1}$ food concentration, egg production rate was lower (by about 2.5 times) than that observed at higher food levels, indicating food quantity limitation. Over the study period, there was a general decline in egg production irrespective of the food concentration at which females were held (Fig. 2B). This could be due to loss of female reproductive ability with age, as observed in other studies (e.g. Durbin et al. 1992). No variation in egg size was observed between the different food treatments in this study (Fig. 2A), contrary to what has been reported for other copepod species (e.g. Calanus helgolandicus: Guisande \& Harris 1995). Hence, it is plausible that the size of an Acartia egg is independent of the quantity of food available to females.

We observed no significant differences in the chemical composition (on a relative basis) between Acartia females, their eggs and the prey. Others have made similar observations in studies involving single prey species (Lee et al. 1971) or copepods that feed nonselectively (Peters et al. 2007).
Copepods exposed to uni-algal diets can satisfy their specific requirement for chemical substances by increasing food intake and investing acquired biochemical excesses into biosynthesis. This could be realistically achieved when ambient food availability is high or saturating. However, low food availability would limit the animals' capacity to 'overfeed' for excesses resources, and as a result may lack the energy to markedly modify the substrates they acquire for biosynthesis. This may explain why biochemical similarities between Rhodomonas baltica and both stages of Acartia tonsa were mostly higher when food availability was low, and decreased with increasing food concentration (Fig. 3A,B).

\section{Biochemical constituents of females and eggs}

Data on chemical composition of zooplankton are inconclusive and at times difficult to interpret. Typically, studies have investigated the elemental composition of zooplankton, and the data show variations in the C:N ratio of zooplankton (e.g. Tande 1982), in some cases by as much as $30 \%$ (Grønvik \& Hopkins 1984). In contrast, reports of zooplankton maintaining a constant chemical composition independent of ambient conditions (i.e. chemical homeostasis) also exist (Hessen 1990). In our study, individual chemical constituents of females did not change with food availability (Fig. 1), despite the fact that that prey density influences grazing rate (e.g. Kiørboe et al. 1985) as well as the efficiency with which the chemical constituents of ingested prey are assimilated (Urabe \& Watanabe 1991, Besiktepe \& Dam 2002). FA content of females was $1.31 \pm 1.33 \mu \mathrm{g}$ ind..$^{-1}$ (mean $\pm \mathrm{SD}$ ), which compares well with the range of 0.07 to $0.1 \mu \mathrm{g}$ ind. ${ }^{-1}$ reported by Ederington et al. (1995) for female Acartia tonsa cultured with different prey items. Published protein and carbohydrate contents of adult Acartia range from 3.40 to 4.49 and 0.12 to $0.77 \mu \mathrm{g}$ ind. ${ }^{-1}$, respectively (Ikeda \& Skjoldal 1980, Kapiris et al. 1997, Rajkumer \& Vasagam 2006). Mean carbohydrate content (1.25 \pm $1.58 \mu \mathrm{g})$ observed per female in this study was comparable to these estimates. The protein composition $(0.51 \pm 0.70 \mu \mathrm{g})$ observed here was relatively low for Acartia but was comparable to data on adults of similar sized copepods such as Euterpina acutifrons (protein content: 0.81 to $2.88 \mu \mathrm{g}$ ind. $^{-1}$; Guisande et al. 2000). Hence, Acartia maintains homeostasis at the biochemical level as reported for other copepod species (Guisande \& Harris 1995). This occurs as many copepods can regulate their post-ingestion processes (e.g. assimilation, metabolism) to meet their specific requirement for chemical substances (Mitra \& Flynn 2005). 
Contrary to the observation made in females, the biochemical composition of eggs changed with food concentration (Fig. 1). This has been observed in other copepod species (Guisande \& Harris 1995, Guisande et al. 2000). Consumers feed first to meet their maintenance requirements, with subsequent egg production possible only when there are excess resources to be invested for egg production. In the presence of adequate but not abundant (i.e. not saturating) food for egg production, it is necessary for consumers to regulate how they use the substances they acquire in order for egg production to be possible. Consequently, this may lead to a decrease in egg production in favour of a composition that meets the minimum requirements for successful egg development (Anderson \& Pond 2000). However, if the level of food is below the regulatory capacity of the animal, then the animal will be constrained to accept surpluses of some biochemicals and/or deficits of others in the eggs. We did not observe significant differences in the carbohydrate and FA content of eggs produced at different food concentrations. On average, carbohydrate and FA content were $0.11 \pm 0.28$ and $0.05 \pm 0.09 \mu \mathrm{g}$ egg $^{-1}$, respectively. These estimates are comparable to data from other studies (Wang et al. 2005, Drillet et al. 2006). Conversely, the protein content of eggs decreased from 0.08 to $0.02 \mu \mathrm{g} \mathrm{egg}^{-1}$ (on average) with increasing food availability. These values are comparable with the total amino acid composition of Acartia tonsa eggs (Drillet et al. 2006, 2008), assuming that amino acids mainly occur in proteins. They caused the total biochemical composition $(\mu \mathrm{g})$ per egg produced by females held at higher food concentration to be significantly less than those produced by food-limited females. To the extent that inadequate food availability is a feature of the natural environments of animals (Bellantoni \& Peterson 1987, Durbin et al. 1992), it may be that this was a consequence of Acartia's reproductive strategy under food-limited conditions.

Interestingly, it has been hypothesised that copepods produce heavier eggs as an adaptation to food-limited environments (e.g. Guisande et al. 1996, Auel 2004). Heavy energy-rich eggs provide adequate internal energy reserves for early ontogenetic lecithotrophic development, making nauplii relatively independent of the prevailing feeding conditions. Even for species not known for lecithotrophic development, having an energy-rich early ontogenetic stage in a food-limited environment may be advantageous for surviving the relatively longer time nauplii may spend before encountering food. However, this strategy may not entirely apply to Acartia. Our results show that protein, an unlikely substrate for energy reserve due to its comparatively low energy content, was the substance responsible for the weight differences between eggs produced at different food concentrations.

Results from several studies indicate that Acartia tonsa produces normal, subitaneous and diapause eggs (e.g. Sullivan \& McManus 1986, Madhupratap et al. 1996). Normal eggs hatch rapidly within the water column. Conversely, both subitaneous and diapause eggs have been described as 'resting eggs' with suppressed development (Marcus 1996). Subitaneous eggs are quiescent eggs that may forego hatching in unfavourable conditions but can hatch as soon as improved environmental conditions are experienced. Diapause, however, is a more profound interruption that routes the metabolic programme of an organism away from direct developmental pathways and into a much more clearly organised break in development (Danks 1987). Thus diapause forces the development of eggs into a refractory phase, which may last from few months to years, during which development does not resume even if conditions are suitable (Marcus 1996). Interestingly, when copepods are food limited or starved, egg hatching success decreases (Ederington et al. 1995, Lacoste et al. 2001). Ephippial (i.e. diapause egg) formation in Daphnia can be caused by extreme starvation (Slobodkin 1954). In Onychodiaptomus birgei, food availability affects the timing as well as the rate of diapause egg production (Walton 1985). Moreover, production of both subitaneous and diapause eggs has been observed in crowded cultures of copepods such as Eurytemora affinis (Ban 1992), Acartia latisetosa (Belmonte 1992) and Diaptomus clavipes (Gehrs \& Martin 1973). These results suggest that stressors such as inadequate resource supply may play a role in resting egg production.

Based on these observations and our results, we hypothesise that food quantity limitation is one mechanism triggering resting egg production in Acartia and that the role of the relatively high egg protein content observed in the low food treatments could be to provide sufficient storage product to maintain metabolism during diapause. This hypothesis is based on the observation that resting copepod eggs contain relatively more proteins than lipids and carbohydrates (Wang et al. 2005). Also, resting eggs have reduced metabolic activity (Romano et al. 1996) and thus may require less energy that could be supplied by respiring protein.

Furthermore, resting eggs sometimes sink onto the seabed where they get buried into anoxic sediment (Marcus et al. 1994). Under such conditions, protein may be the appropriate substrate for respiration because less oxygen is required for the catabolism of protein than for lipids and carbohydrates (Marcus 1996). Conversely, production of lipid-rich eggs under low food conditions may be physiologically advantageous for species that do not produce resting eggs (see Auel 
2004). Here lipids could provide nauplii with adequate energy reserves to survive the relatively longer time animals may require before encountering food in a low-food environment.

A major question as yet unanswered is whether the protein-rich eggs produced by food-limited copepods in the present study were diapause and subitaneous eggs. We did not measure hatching success in this study due to the need for high quantities of eggs for the biochemical analysis. As a consequence, we cannot currently ascertain whether the protein-rich eggs produced by food-limited females were subitaneous or diapause eggs. We are currently investigating this as part of an experiment to test this hypothesis. Hence we will discuss why it may be advantageous for Acartia to produce resting eggs when confronted with poor feeding conditions without alluding to the type of egg.

Producing resting egg under food-limited conditions could be crucial for the persistence of the species for 2 major reasons. First, resting eggs, if not preyed upon, could serve as a naupliar recruitment source when food conditions improve or diapause is broken (Marcus 1996). The biochemical weight of the eggs produced in the food-limited environment was significantly higher than those produced in relatively higher food treatments (Fig. 1). However, egg size remained the same among females held at different food concentrations (Fig. 2A). Therefore, eggs produced in the food-limited treatment may be denser than those produced by females provided with saturated food levels. This could increase the velocity with which eggs sink (Wang et al. 2005) for eventual burial into the seabed if they are resting eggs. Since resting eggs can survive many years of burial, their slow accumulation in the seabed could provide copepods with a pool of genetic information, i.e. an egg bank according to Marcus et al. (1994), that may slow down the rate of evolutionary change (Hairston \& De Stasio 1988). Hence, the second benefit Acartia may derive from producing resting eggs under food-limited conditions is that the perpetuation of the species would be ensured in the habitat to which it is adapted. During periods of adequate food conditions, this reproductive strategy against resource limitation may not be necessary since early nauplii can benefit from readily available prey.

Our results demonstrate that food quantity limitation does not affect the biochemical composition of adult Acartia tonsa, but it does affect production rate and the biochemical composition of eggs. The major assumption in this study was that differences in the availability of food to females would result in dissimilar biochemical composition of eggs due to the demand for maintenance by females. We observed a significant effect of food availability on the biochemical composition of eggs produced by Acartia females held at differ- ent food concentrations (Fig. 1). We argue that food availability influences the reproductive strategy of Acartia females vis-à-vis the production of resting eggs under food-limited conditions.

Acknowledgements. This work was supported by grants from EU FP-6 (EUR-OCEANS to M.S.J.) and the NSERC of Canada (post-doctoral fellowship to R.W.C.). Helpful comments were received on an earlier draft of this manuscript from the editor and 3 anonymous reviewers.

\section{LITERATURE CITED}

Alonzo P, Mayzaud P, Razouls S (2000) Egg production dynamics, biochemical composition and hatching success of the subantarctic copepod Paraeuchaeta antarctica: laboratory study. Mar Ecol Prog Ser 205:219-227

Anderson T, Pond DW (2000) Stoichiometric theory extended to micronutrients: comparison of the roles of essential fatty acids, carbon, and nitrogen in the nutrition of marine copepods. Limnol Oceanogr 45:1162-1167

Auel H (2004) Egg size and reproductive adaptation among Arctic deep-sea copepods (Calanoida, Paraeuchaeta). Helgol Mar Res 58:147-153

Ban S (1992) Effects of photoperiod, temperature, and population density on induction of diapause egg production in Eurytemora affinis (Copepoda: Calanoida) in Lake Ohnuma, Hokkaido, Japan. J Crustac Biol 12:361-367

> Bellantoni DC, Peterson WT (1987) Temporal variability in egg production rates of Acartia tonsa Dana in Long Island Sound. J Exp Mar Biol Ecol 107:199-208

Belmonte G (1992) Diapause egg production in Acartia (Paracartia) latisetosa (Crustacea, Copepoda, Calanoida). Boll Zool 59:363-366

Besiktepe S, Dam HG (2002) Coupling of ingestion and defecation as a function of diet in the calanoid copepod Acartia tonsa. Mar Ecol Prog Ser 229:151-164

Cowles TJ, Olson RJ, Chisholm SW (1988) Food selection by copepods: discrimination between cells on the basis of food quality. Mar Biol 100:41-49

Cushing GH (1990) Plankton production and year class strength in fish populations: an update of the match/mismatch hypothesis. Adv Mar Biol 26:249-293

Danks HV (1987) Insect dormancy: an ecological perspective. Tyrell Press, Gloucester

Drillet G, Jørgensen NOG, Sørensen TF, Ramløv H, Hansen BW (2006) Biochemical and technical observations supporting the use of copepods as live feed organisms in marine larviculture. Aquac Res 37:756-772

Drilet G, Jepsen PM, Højgaard JK, Jørgensen NOG, Hansen BW (2008) Strain-specific vital rates in four Acartia tonsa cultures II: life history traits and biochemical contents of eggs and adults. Aquaculture 279:47-54

> Dubois M, Gilles KA, Hamilton JK, Rebers PA, Smith F (1956) Colorimetric method for determination of sugars and related substances. Anal Chem 28:350-356

> Durbin EG, Durbin AG, Campbell RG (1992) Body size and egg production in the marine copepod Acartia hudsonica during a winter-spring diatom bloom in Narragansett Bay. Limnol Oceanogr 37:342-360

> Ederington MC, McManus GB, Harvey HR (1995) Trophic transfer of fatty acids sterols and triterpenoid alcohol between bacteria, a ciliate and the copepod Acartia tonsa. Limnol Oceanogr 40:860-867

Folch J, Lees M, Stanley GHS (1957) A simple method for the isolation and purification of total lipids from animal tissues. J Biol Chem 226:497-509 
Gehrs CW, Martin BD (1973) Production of resting eggs by Diaptomus clavipes Schacht (Copepoda,Calanoida). Am Nat 91:486-488

Grønvik S, Hopkins CCE (1984) Ecological investigations of the zooplankton community of Balsfjorden, northern Norway: generation cycle, seasonal vertical distribution, and seasonal variations in body weight and carbon and nitrogen content of the copepod Metridia longa (Lubbock). J Exp Mar Biol Ecol 80:93-107

Guisande C, Harris R (1995) Effect of total organic content of eggs on hatching success and naupliar survival in the copepod Calanus helgolandicus. Limnol Oceanogr 40: 476-482

$>$ Guisande C, Sanchez I, Maneiro I, Miranda A (1996) Tradeoff between offspring number and offspring size in the marine copepod Euterpina acutifrons at different food concentrations. Mar Ecol Prog Ser 143:37-44

Guisande C, Riveiro I, Maneiro I (2000) Comparisons among the amino acid composition of females, eggs and food to determine the relative importance of food quantity and food quality to copepod reproduction. Mar Ecol Prog Ser 202:135-142

> Hairston NG Jr, De Stasio BT Jr (1988) Rate of evolution slowed by a dormant propagule pool. Nature 336:239-242

Herbert D, Phipps PJ, Strangem RE (1971) Chemical analysis of microbial cells. In: Norris JR, Ribbons DW (eds) Methods in microbiology. Academic Press, London, p 209-344

Hessen DO (1990) Carbon, nitrogen and phosphorus status of Daphnia magna at varying food conditions. J Plankton Res 12:1239-1249

Huntley M, Boyd C (1984) Food-limited growth of marine zooplankton. Am Nat 124:455-478

Ikeda T, Skjoldal HR (1980) The effect of laboratory conditions on the extrapolation of experimental measurements to the ecology of marine zooplankton VI. Changes in physiological activities and biochemical components of Acetes sibogae australis and Acartia australis after capture. Mar Biol 58:285-293

Jónasdóttir SR, Kiørboe T (1996) Copepod recruitment and food composition: Do diatoms affect hatching success? Mar Biol 125:743-750

Kapiris K, Miliou H, Moraitou-Apostolopoulou M (1997) Effects of formaldehyde preservation on biometrical characters, biomass and biochemical composition of Acartia clausi (Copepoda, Calanoida). Helgol Meeresunters 51: 95-106

Kattner G, Fricke HSG (1986) Simple gas-liquid chromatographic method for the simultaneous determination of fatty acids and alcohols in wax esters of marine organisms. J Chromatogr A 361:263-268

> Kiørboe T, Møhlenberg F, Hamburger K (1985) Bio-energetics of the planktonic copepod Acartia tonsa: relation between feeding, egg production and respiration, and composition of specific dynamic action. Mar Ecol Prog Ser 26:85-97

Lacoste A, Poulet SA, Cueff A, Kattner G, Ianora A, Laabir M (2001) New evidence of the copepod maternal food effects on reproduction. J Exp Mar Biol Ecol 259:85-107

> Lee RF, Nevenzel JC, Paffenhöfer GA (1971) Importance of wax esters and other lipids in the marine food chain: phytoplankton and copepods. Mar Biol 9:99-108

Lee RF, Hagen W, Kattner G (2006) Lipid storage in marine zooplankton. Mar Ecol Prog Ser 307:273-306

Madhupratap M, Nehring S, Lenz J (1996) Resting eggs of marine zooplankton (Copepoda \& Cladocera) from Kiel Bay and adjacent waters (southwestern Baltic). Mar Biol 125:77-87

Marcus NH (1996) Ecological and evolutionary significance of resting eggs in marine copepods: past, present and future studies. Hydrobiologia 320:141-152

Marcus NH, Lutz RV, Burnett W, Cable P (1994) Age, viabil- ity, and vertical distribution of zooplankton resting eggs from an anoxic basin: evidence of an egg bank. Limnol Oceanogr 39:154-158

> Mayzaud P (1976) Respiration and nitrogen excretion of zooplankton. IV. The influence of starvation on the metabolism and the biochemical composition of some species. Mar Biol 37:47-58

McVej JP (1993) CRC handbook on mariculture, 2nd edn, Vol 1. CRC press, Boca Raton, FL

Mitra A, Flynn KJ (2005) Predator-prey interactions: Is 'ecological stoichiometry' sufficient when good food goes bad? J Plankton Res 27:393-399

> Peters J, Dutz J, Hagen W (2007) Role of essential fatty acids on the reproductive success of the copepod Temora longicornis in the North Sea. Mar Ecol Prog Ser 341:153-163

Pond D, Harris R, Head R, Habour D (1996) Environmental and nutritional factors determining seasonal variability in the fecundity and egg viability of Calanus helgolandicus in coastal waters off Plymouth, UK. Mar Ecol Prog Ser 143:45-63

Rajkumar M, Vasagam KPK (2006) Suitability of the copepod, Acartia clausi as a live feed for seabass larvae (Lates calcarifer Bloch): compared to traditional live-food organisms with special emphasis on the nutritional value. Aquaculture 261:649-658

Roman MR (1991) Pathways of carbon incorporation in marine copepods: effect of developmental stage and food quantity. Limnol Oceanogr 36:796-807

Romano G, Ianora A, Santella L, Miralto A (1996) Respiratory metabolism during embryonic subitaneous and diapause development in Pontella mediterranea (Crustacean, Copepoda). J Comp Physiol B 166:157-163

Sessler AM, Ntambi JM (1998) Polyunsaturated fatty acid regulation of gene expression. J Nutr 128:923-926

Slobodkin LB (1954) Population dynamics in Daphnia obtusa Kurz. Ecol Monogr 24:69-88

Smith PK, Krohn RI, Hermanson GT, Mallia AK and others (1985) Measurement of protein using bicinchoninic acid. Anal Biochem 150:76-85

Sterner WR (1997) Modelling interactions of food quality and quantity in homeostatic consumers. Freshw Biol 38: 473-481

Sullivan BK, McManus LT (1986) Factors controlling seasonal succession of the copepods Acartia hudsonica and A. tonsa in Narragansett Bay, Rhode Island: temperature and resting egg production. Mar Ecol Prog Ser 28:121-128

Tande KS (1982) Ecological investigations on the zooplankton community of Balsfjorden, northern Norway: generation cycles, and variations in body weight and body content of carbon and nitrogen related to overwintering and reproduction in the copepod Calanus finmarchicus (Gunnerus). J Exp Mar Biol Ecol 62:129-142

Tang KW, Dam HG, Feinberg LR (1998) The relative importance of egg production rate, hatching success, hatching duration and egg sinking in population recruitment of two species of marine copepods. J Plankton Res 20:1971-1987

Tester PA, Turner JT (1990) How long does it take copepods to make eggs? J Exp Mar Biol Ecol 141:169-182

> Urabe J, Watanabe Y (1991) Effect of food concentration on the assimilation and production efficiencies of Daphnia galeata G.O. Sars (Crustacea: Cladocera). Funct Ecol 5: 635-641

Walton WE (1985) Factors regulating the reproductive phenology of Onychodiaptomus birgei (Copepoda: Calanoida). Limnol Oceanogr 30:167-179

Wang W, Jiang X, Wu L, Li S (2005) Differences in the density, sinking rate and biochemical composition of Centropages tenuiremis (Copepoda: Calanoida) subitaneous and diapause eggs. Mar Ecol Prog Ser 288:165-171 